\title{
Stakeholder Analysis in Utilizing of Environmental Services and Natural Attractions in Tuk Semuncar Utilization Zone of Gunung Merbabu National Park: A literature review
}

\author{
Muhammad Arif Setiawan ${ }^{1, *}$ and Fuad Muhammad $^{2}$ \\ ${ }^{1}$ Master Program of Environmental Science, School of Postgraduate Studies, Diponegoro University, Semarang - Indonesia \\ ${ }^{2}$ Faculty of Science and Mathematics, Diponegoro University, Semarang - Indonesia
}

\begin{abstract}
Many stakeholders in the utilizing of environmental services and natural attraction of Tuk Semuncar Utilization Zone needs to get the attention of the Gunung Merbabu National Park Officer. The existence of natural resources has an important role for the life of the community, making the complexity of the relationship between various parties who have interests in natural resource management. The existence of stakeholders and their interests should receive attention and be considered to be accommodated as an effort to prevent the occurrence of losses to the conservation area of Gunung Merbabu National Park. Every stakeholder's interest can have a positive and negative impact on other stakeholders. Stakeholder analys is can help in understanding the conflict on the utilizing of environmental services and natural attraction that is happening, as well as input strategy in involving stakeholders for the achievement of goals.
\end{abstract}

\section{Introduction}

Indonesia has the potential of valuable natural resources, partly within the conservation area. The potential has an important position and role for the Indonesian nation as a development capital. The management of conservation areas and their development has the objective to promote the conservation of biological natural resources and their ecosystems so as to support efforts to improve the welfare of the community and to support the success in achieving sustainable development.

As a conservation area surrounded by densely populated settlements, the area of Gunung Merbabu National Park is inseparable from public pressure. The area of Gunung Merbabu National Park becomes an integral part of the life of the people around it. The community has strong interactions with the natural resources of the Gunung Merbabu National Park area in economic, social and cultural aspects. Communities hereditary to meet the needs of life from natural resources in the forest area of Mount Merbabu which is currently designated as Gunung Merbabu National Park area. These community activities can affect the sustainability of natural resources and the ecosystem of Gunung Merbabu National Park. This makes the area of conservation gets high pressure from the community so that it can threaten the preservation of natural resources and its ecosystem. States that all conservation areas that are public assets and managed by the government for public interest have been damaged, widespread, or contested by various parties wishing to exploit the area for other purposes [1].
Determination of Gunung Merbabu National Park area as government step for ecological protection of life buffer system, preservation of plant species diversity, wildlife and its constituent ecosystem, sustainable use of natural resources and ecosystem for science, education, research, cultivation support and tourism [2]. Ecologically, the Gunung Merbabu National Park area becomes a water catchment area for the surrounding areas and water source producers. Gunung Merbabu National Park area there is also the potential of nature tourism that can be developed as a tourist destination.

In addition to potential water sources, Tuk Semuncar Utilization Zone has a natural beauty that has the potential to become a natural tourist destination. The natural tourism opportunity of Tuk Semuncar Utilization Zone is used by some people to get the economic benefit. The number of natural tourist visitors to the Tuk Semuncar Utilization Zone caused conflict within the community. Nature tourism activities have a negative impact on community water utilizing. Conflict is allegedly a difference in interests and differences in ownership rights. As a measure to reduce conflict, the Gunung Merbabu National Park Officer decided to close all natural tourism activities to the Tuk Semuncar Utilization Zone indefinitely. Actually, the District Government sees the potential of nature tourism Tuk Semuncar Utilization Zone can be developed to improve the welfare of the surrounding community. However, until now there has been no agreement between interested parties to exploit that potential. 


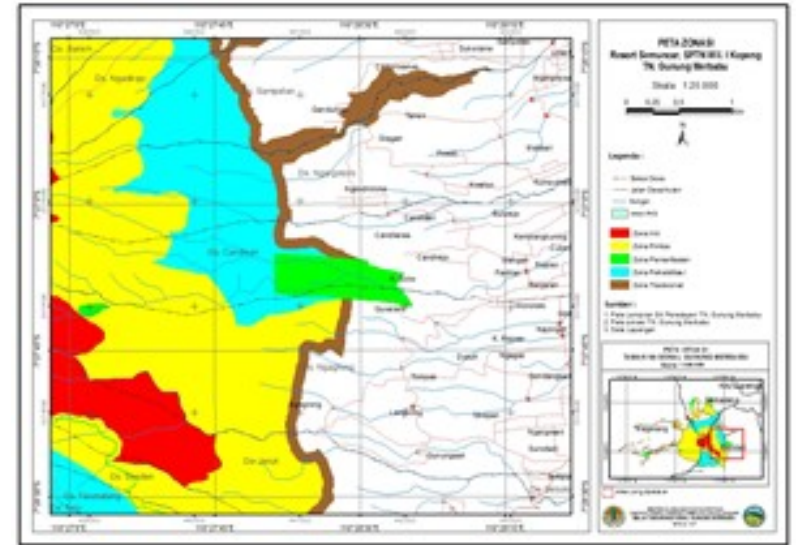

Fig. 1. Map of Tuk Semuncar Utilization Zone of Gunung Merbabu National Park

Tuk Semuncar Utilization Zone is a part of Gunung Merbabu National Park area which has abundant water resources potential and is very important for the livelihood and economy of surrounding communities [2], [3]. There are two large springs in the Tuk Semuncar Utilization Zone. The surrounding community named the two springs as Tuk Semuncar and Tuk Sipendok. Both springs flow into a river whose water is used commercially and non commercially. The people who come from the surrounding villages are very dependent on the water source.

Budimanta, who a key person, stated that the existence of natural resources has an important role for the life of the community, making the complexity of the relationship between various stakeholders in natural resources management [4]. The complexity of relations between stakeholders raises social and environmental problems that can be a constraint in the management of Gunung Merbabu National Park conservation area. Thus, an understanding of the existence and role of stakeholders is important in realizing good management and environmental, social and economic benefits [5].

The number of stakeholders in the utilizing environment services and natural attraction Tuk Semuncar Utilization Zone needs to get the attention of Gunung Merbabu National Park Officer. Utilizing of environmental services and natural attraction of Tuk Semuncar Utilization Zone by one party may cause harm to the interests of other parties. The existence of stakeholders and their interests should receive attention and be considered to be accommodated as an effort to prevent the occurrence of losses to conservation areas.

Stakeholders management is important to minimize problems in the joint use of environmental services and nature attraction of Tuk Semuncar Utilization Zone so that it can provide optimal benefits for all stakeholders. It can help improve management effectiveness and synergize the interests of all stakeholders based on the understanding and agreement in accordance with the laws and regulations. Success in managing stakeholders interest in the utilizing environmental services and nature attraction of Tuk Semuncar Utilization Zone will contribute positively to the Gunung Merbabu National Park natural resources management.

\section{Who are Stakeholders?}

The definition of stakeholders is individuals or groups that can be impacted or affected by the success of an organization's goals [6]. Anyone who impacts and / or is affected by development policies, programs and activities. They can be men or women, communities, socioeconomic groups, or institutions in dimensions at every level of society [7]. Each individual / group has the resources and needs of each who must be represented in the decision-making process in development activities. As parties either individually or in groups that can be influenced and / or influencing decision-making as well as achieving the objectives of an activity [8].

In the implementation of development programs, the term stakeholders are used to describe communities or organizations that are affected by activities or policies, in which a party does not always receive a fair impact. Some parties may bear the costs and some will actually benefit from an activity or policy [9].

Crosby argues that broadly the stakeholders are divided into three groups, (a) Main stakeholders, those who receive positive or negative impacts (outside the willingness) of an activity, (b) Supporting stakeholders, ie parties who mediate in assisting the process of delivering activities. They can be classified on behalf of donors, executives, supervisors, and advocacy organizations such as government organizations, NGOs, and private parties. In some activities, support stakeholders may be individuals or key groups with both formal and informal interests, (c) Key stakeholders, ie those with strong or important influences related to issues, needs, and concerns for the smoothness of activities [10].

\section{Stakeholders Analysis}

Stakeholder analysis is defined as a process for (1) defining aspects of social and natural phenomena that are influenced by decisions or actions; (2) identifying individuals, groups and organizations affected by or may affect parts of the phenomenon; and (3) prioritizing an individual and group for involvement in decision-making processes [11].

Stakeholder analysis is useful in identifying communities or groups of people most affected by the impact or impact of a development activity [9]. The analysis is also useful in determining priorities about the community or community groups needed in the implementation of development activities and benefits for them. Stakeholder analysis can assist in understanding the current conflict of land resource use [12].

Grimble and Chan argues that stakeholders' analysis of natural resource management has the following main objectives, (a) Improve the effectiveness of policy implementation by explicitly considering the interests and challenges of stakeholders regarding the implementation of a policy, identifying and managing stakeholder conflicts over natural resources, and providing early consideration for ways to build 
togetherness, complementary interests, and opportunities for cooperation and compromise, (b) Addressing the social impacts of a policy by breaking down the analysis to separately assess the interests and impacts of interventions on different stakeholders [8].

Stakeholder analysis is conducted by: (a) identifying stakeholders, (b) mapping and categorizing stakeholders, and (c) investigating relationships among stakeholders [11]. Identification of stakeholders to identify groups / organizations / individuals who have a negative / positive impact on the activities of the utilization of environmental services and natural tourism. Stakeholder mapping is done by using interest rate and influence matrix to classify stakeholders as key player, context setter, subject, and crowd [11]. The mapping of stakeholders will help the Mount Merbabu National Park Officer in the involvement of stakeholders in the achievement of objectives Investigation of relationships among stakeholders can be useful to minimize conflicts that occur so as not to cause harm to natural resources There are three types of relationships among stakeholders, cooperating, complementary, and conflict.

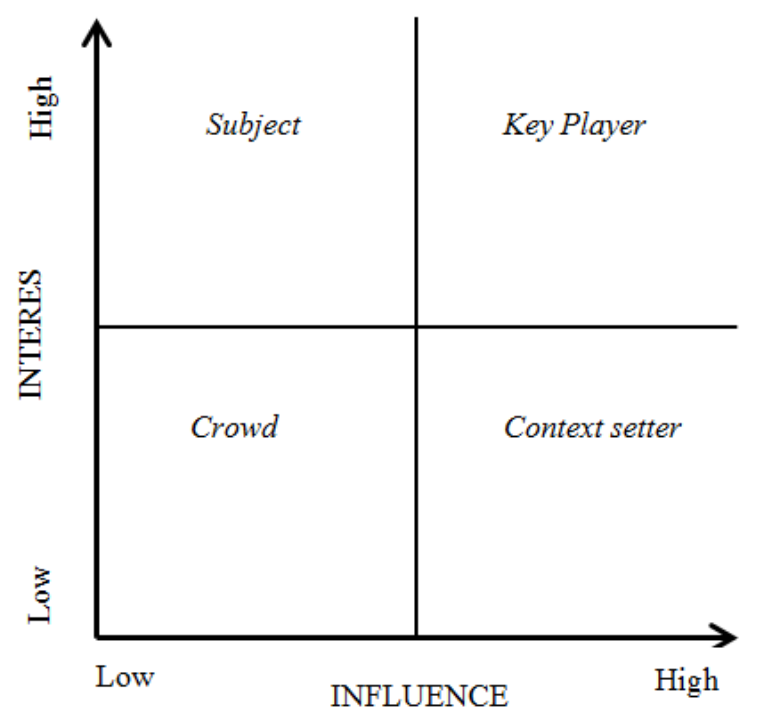

Fig. 1. Stakeholders interest and stakeholders influence matrix

\section{Stakeholders Perception Stakeholders Participation}

Some important things in stakeholder analysis that also need to know is the stakeholders perception and stakeholders participation.

\subsection{Stakeholders Perception}

Stakeholder perceptions need attention in integrating their roles and tasks. This is important because perceptions of each stakeholder may differ from one to another, both individuals and groups [10]. Feldman argues that the perception can be a view of policies, programs, activities, and promotions made by external parties to local communities [10]. While Gabriel states that knowing the perception of each stakeholders is a process in the context of task integration and the role of stakeholders in a collective action [10]. Golder and Gawler argue that analysis of stakeholders' perceptions is important because ultimately each activity will depend on selected stakeholders with whom they will work together to achieve a goal [13].

\subsection{Stakeholders Participation}

Participation is a process whereby all parties can shape and engage in all development initiatives. In this case, anyone can play a role and actively have control over his own life, take a role in society, and become more involved in development [14]. Participation is a medium in achieving the objectives of the implementation of activities. Through participation, stakeholders are expected to formulate and simultaneously implement joint actions in achieving the objectives [10].

Communities are the most affected stakeholders of an activity. The success of a program is largely determined by the high level of community participation. Community participation is a process involving people to participate in local planning, implementation and management activities. The readiness of local governments and communities to accept responsibility and work together in environmental management activities is an important value of this participation. In addition, a commitment to managing resources, skills and knowledge to achieve goals, and respecting the capabilities and capacities of all partners is the most important element in the success of these community participation activities[15].

\section{Conclusion}

Tuk Semuncar Utilization Zone of Gunung Merbabu National Park has potential of environmental services and natural attraction. Potential is utilized by many parties. Knowledge of interested parties can minimize conflicts of interest in the utilization of environmental services and natural tourism. Stakeholder analysis can be used to mapping stakeholders by identifying, perceptions, participation, and stakeholder roles. The results of stakeholder analysis can be used as input in formulating strategies in the conservation areas management.

\section{References}

1. A. Mulyana., "Kebijakan pengelolaan zona khusus dapatkah meretas kebuntuan dalam menata ruang Taman Nasional di Indonesia?,” Bogor, 2010.

2. Balai TNGMb, "Rencana Pengelolaan Taman Nasional Gunung Merbabu 2014 - 2023,” Jawa Tengah, 2014.

3. H. Gunawan, M. Bismark, and H. Krisnawati, "Kajian Sosial Ekonomi Masyarakat Sekitar Sebagai Dasar Penetapan Tipe Penyangga Taman 
Nasional Gunung Merbabu, Jawa Tengah,” J. Penelit. Hutan dan Konserv. Alam, vol. 10, no. 2, pp. 103-119, 2013.

4. I. Marina and H. A. Dharmawan, "Analisis Konflik Sumberdaya Hutan di Kawasan Konservasi," J. Transdisiplin Sosiologi, Komunikasi, dan Ekol. Mns., vol. 5, no. 1, pp. 90-96, 2011.

5. I. Alviya, E. Y. Suryandari, R. Maryani, and M. Z. Muttaqin, "Meningkatkan Peran pemangku Kepentingan Dalam Pengelolaan Wilayah Hulu Daerah Aliran Sungai Ciliwung” J. Penelit. Sos. dan Ekon. Kehutan., vol. 13, no. 2, pp. 121-134, 2016.

6. J. M. Bryson, "What To Do When Stakeholders Matter: A Guide to Stakeholder Identification and Analysis Techniques," Minneapolis, 2004.

7. J. Gonsalves, Participatory Research and Development for Sustainable Agriculture and Natural Resource Management: A Sourcebook. Volume 1: Understanding Participatory Research and Development. Philippines and International Development Research Centre, Ottawa, Canada, 2005.

8. A. K. Wakka, “Analisis Stakeholders Pengelolaan kawasan Hutan Dengan Tujuan Khusus(KHDTK) Mengkendek, Kabupaten Tana Toraja, Provinsi Sulawesi Selatan” J. Penelit. Kehutan. Wallacea, vol. 3, no. 1, pp. 47-55, 2014.

9. D. Race and J. Millar, Social and Community Dimensions to ACIAR Projects (ACIAR Training Manual). Canberra: Australian Centre for International Agricultural Research, 2008.

10. M. Iqbal, “Analisis Peran Pemangku Kepentingan dan Implementasinya Dalam Pembangunan Pertanian,” J. Litbang Pertan., vol. 26, no. 3, pp. 89-99, 2007.

11. M. S. Reed. J. Environ. Manage., vol. 90, no. 5, pp. 1933-1949, 2009.

12. P. Mushove and C. Vogel, Glob. Environ. Chang., vol. 15, pp. 184-198, 2005.

13. I. Alviya, M. Salminah, V. B. Arifanti, R. Maryani, and E. Syahadat, "Persepsi Para Pemangku Kepentingan Terhadap Pengelolaan Lanskap Hutan di Daerah Aliran SUngai Tulang Bawang", J. Penelit. Sos. dan Ekon. Kehutan., vol. 9, no. 4, pp. 171-184, 2012.

14. Syahyuti, Partisipasi. Bogor: Pusat Analisis Sosial Ekonomi dan Kebijakan Pertanian, 2006.

15. R. Sahai, "Community Participation in Environmental Management: Role of Women," Int. Conf. Recent Res. Dev. Environ. Soc. Sci. Humanit., pp. 173-180, 2015. 